\title{
Kraj Saary a początki integracji europejskiej
}

Kraj Saary (niem. Saarland), obecny kraj związkowy Republiki Federalnej Niemiec, jest obszarem pogranicza niemiecko-francuskiego. Przez większość swej historii był częścią Świętego Cesarstwa Rzymskiego Narodu Niemieckiego by pod koniec XVII stulecia znaleźć się w granicach Francji w ramach tzw. polityki reunionów, prowadzonej przez Ludwika XIV (Rudolf, Oswalt, 2009, s. 98-99). Jego „niemieckość” wydaje się niezwykle trudna do zakwestionowania, choć w imię interesów gospodarczych Francja takie próby - nieskutecznie - podejmowała.

Celem artykułu jest przedstawienie położenia tego regionu w okresie natężonych starań o nawiązanie głębszej współpracy politycznej i ekonomicznej zachodniej części kontynentu europejskiego po 1945 roku. Cezury czasowe rozważań obejmują okres od zakończenia II wojny światowej (z pewnymi odniesieniami do czasów między wojnami) do włączenia Saary w skład Republiki Federalnej Niemiec.

Hipoteza Autora sprowadza się do stwierdzenia, iż polityka Francji wobec Kraju Saary miała na celu z jednej strony przede wszystkim uzyskanie korzyści gospodarczych, z drugiej zaś próbowano szachować nowopowstałą RFN żądaniami politycznymi, dotyczącymi postulowanej niezależności Saary. Kluczowe zdają się odpowiedzi na pytania: 1) w jakim stopniu odniesienia Francji i RFN do Kraju Saary wpływały na proces integracji europejskiej, 2) na ile realne były francuskie starania o uznanie niezależności Saary i stworzenia z niej państwa o statusie europejskim; wreszcie 3) co przyczyniło się do fiaska planów Francji wobec tego regionu.

W rozważaniach wykorzystano metody badawcze typowe dla nauk o polityce i administracji: w dużej mierze metodę historyczną, pozwalającą na nakreślenie kontekstu powstania problemu oraz metodę systemową i metodę porównawczą. Przywołany problem stanowi studium przypadku.

\section{Kraj Saary w okresie międzywojennym i w czasie II wojny światowej}

Spór niemiecko-francuski o ten obszar przybrał na sile po zakończeniu I wojny światowej. Warto zaznaczyć, że istotnego znaczenia nabierał wówczas argument natury gospodarczej, a nie etnicznej. Pod względem etnicznym obszar ten był zdecydowanie niemiecki i strona francuska - jeśli chciałaby podnosić poważne argumenty - nie mogła go w zasadzie używać. Kraj Saary był zasobny w złoża węgla, tam też funkcjonowały wysoko rozwinięte huty żelaza. Przedstawiał zatem ważne znaczenie w ewentualnym wspomożeniu powojennej gospodarki państwa francuskiego. 
W ramach powojennych reparacji (za kopalnie zniszczone podczas wojny w północno-wschodniej Francji) Francja mogła wykorzystywać kopalnie Saary i czerpać z nich zyski. Obszar znalazł się pod zarządem międzynarodowym, o jego sprawach decydowała 5-osobowa komisja Ligi Narodów, którą zobowiązano do przeprowadzenia po 15 latach referendum, które miało zdecydować definitywnie o statusie pogranicznego terytorium: utrzymaniem status quo, przyłączeniem do Niemiec lub do Francji (Batowski, 2001, s. 39, 230). Wcześniej, mimo zabiegów ministra spraw zagranicznych Republiki Weimarskiej Gustava Stresemanna i jego francuskiego odpowiednika Aristide'a Brianda, nie udało się obu stronom dojść do porozumienia. W głosowaniu przeprowadzonym 13 stycznia 1935 r. 90,76\% biorących w nim udział opowiedziało się za powrotem do Niemiec, $8,84 \%$ oddało głos za pozostawieniem status quo a zaledwie $0,4 \%$ chciało włączenia do Francji. 1 marca tegoż roku Saarę włączono do Rzeszy, ta ostatnia zakupiła także od Francji kopalnie za niezwykle wysoką sumę 150 milionów marek ${ }^{1}$ (Elzer, 2008, s. 48-49).

Wynik głosowania nie mógł w zasadzie dziwić, bowiem zamieszkiwała tam ludność pochodzenia niemieckiego, Francuzi byli nieliczni. Tego układu stosunków etnicznych nie zmieniła II wojna światowa. Klęska nazistowskich Niemiec spowodowała, iż przyszłość pogranicznego Kraju Saary ponownie stanęła pod znakiem zapytania.

\section{Powojenna zależność od Francji}

Po zakończeniu wojny cztery mocarstwa przejęły władzę nad obszarem Niemiec, z którego po konferencji poczdamskiej wyłączono definitywnie terytoria przejęte przez Polskę i ZSRR. Jednym z tych mocarstw była Francja, choć jej wkład w zwycięstwo nad III Rzeszą był znacząco mniejszy niż w przypadku pozostałych państw. Mimo to państwo francuskie otrzymało jedną z czterech stref okupacyjnych.

W skład francuskiej strefy weszła m.in. Saara. Bez wątpienia celem władz francuskich było maksymalne osłabienie Niemiec, nawet ich podział, co z czasem napotykało na opór Stanów Zjednoczonych i Wlk. Brytanii. Francuzi wykazywali także daleko idące zainteresowanie Nadrenią (i nadaniem jej ewentualnie statusu międzynarodowego) i właśnie Saarą. Powód miał naturę gospodarczą - na obu obszarach znajdowały się kopalnie i zakłady przemysłu ciężkiego, mogące znacząco przyczynić się do rozwoju francuskiej gospodarki. Cele gospodarcze przyświecały też Paryżowi w kolejnych latach.

Jeszcze w maju 1945 r. amerykańskie władze wojskowe utworzyły nową jednostkę administracyjną o nazwie „Saarland-Pfalz-Südhessen” zamienioną wkrótce na „Mittelrhein-Saar", którą z kolei zlikwidowali Francuzi po przejęciu zwierzchności na tym obszarze. Francja nie mogła sobie pozwolić na bezpośrednie włączenie okupowanego obszaru w swoje granice, w praktyce doszło do powstania protektoratu francuskiego o ograniczonej autonomii, o czym mowa w dalszej części artykułu. Co charaktery-

${ }^{1}$ W 1935 r. w ramach III Rzeszy utworzono nową jednostkę organizacyjną o nazwie Saarland. W 1940 r. obszar ten połączono z Palatynatem w Saarpfalz, a w 1941 r. powstała tzw. Westmark (z włączeniem do niej Lotaryngii). Były to twory sztuczne, niemające uzasadnienia we wcześniejszym podziale administracyjnym. 
styczne, tak Francja, jak i Wlk. Brytania i USA nie prezentowały na arenie międzynarodowej konkretnego pomysłu dotyczącego przyszłości Saary.

Pod koniec 1946 r. na polecenie francuskiego ministra spraw zagranicznych Leona Bluma gen. Marie Pierre Koenig, naczelny dowódca francuskich sił okupacyjnych w Niemczech, doprowadził do blokady granicy Saary z resztą terytorium okupowanych Niemiec, granica została obsadzona przez francuskich celników. Blokada dotyczyła przemieszczania się osób, dóbr i kapitału. W kolejnych dniach Paryż podjął działania mające na celu urzeczywistnienie unii gospodarczej i celnej. W kwietniu 1947 r. wprowadzono jako środek płatniczy markę Saary zastąpioną z czasem frankiem francuskim ${ }^{2}$. Wydarzenia te należy uznać za początek bliższych związków z Francją, zarówno w sensie politycznym, jak i gospodarczym (Elzer, 2008, s. 51-55).

W celu koordynacji działań Francuzi utworzyli specjalną komisję, której podlegało dalsze kształtowanie związków gospodarczych między oboma obszarami. Paryż posuwał się coraz dalej w swoich planach, o czym świadczy memorandum z 10 kwietnia 1947 r., w którym dano do zrozumienia, iż celem Francji jest oddzielenie Saary od Niemiec, wprowadzenie obywatelstwa Kraju Saary, zapewnienie bezpieczeństwa i reprezentowanie za granicą przez Francję, wreszcie wypracowanie konstytucji, w której istotna rola miała zostać przypisana tzw. Wysokiemu Komisarzowi jako gwarantowi związków gospodarczych Francji z Saarą ${ }^{3}$ (Elzer, 2008, s. 55-56).

Wydaje się, iż wymienione działania, w dużej mierze będące jednostronną decyzją Francji, były możliwe z powodu narastających sprzeczności między aliantami zachodnimi a Związkiem Radzieckim co do dalszego kształtu okupacji pokonanych Niemiec. Tereny administrowane przez Francję nie weszły w skład Bizonii, lecz zarówno w Londynie, jak i w Waszyngtonie starano się o jej włączenie w projekt połączenia zachodnich stref okupacyjnych, co najpierw przybrało formę Trizonii, wreszcie utworzenia Republiki Federalnej Niemiec (1949). Można zatem sformułować tezę, iż Francja wykorzystała sprzeczności międzyalianckie, aby w Saarze prowadzić politykę faktów dokonanych. Stany Zjednoczone i Wlk. Brytania nigdy formalnie nie uznały działań francuskich w Kraju Saary, w praktyce miało jednak miejsce przyzwolenie na tę aktywność.

Faktyczne wpływy francuskie na obszarze Saary były budowane poprzez obsadzanie istotnych stanowisk osobami zaufanymi, to samo dotyczyło funkcjonowania partii i związków. Wydalono osoby powiązane z rządami nazistowskimi. Najistotniejszą osobą wpływającą na stosunki w Kraju Saary ${ }^{4}$ był pochodzący z Alzacji Gilbert Grandval, pełniący najpierw funkcję gubernatora wojskowego, następnie Wysokiego Komisarza (od 1948 r.), wreszcie szefa misji dyplomatycznej w randze ambasadora (od 1952 r. do lipca 1955 r.). Partie polityczne, na czele z cieszącą się zdecydowanie

${ }^{2} \mathrm{Na}$ nic zdały się protesty Związku Radzieckiego zwracającego uwagę na fakt, iż w ten sposób Saara została wyjęta spod kompetencji Sojuszniczej Rady Kontroli. ZSRR nigdy nie pogodził się z tymi zmianami, dając temu wielokrotnie wyraz.

3 W czerwcu 1947 r. przeprowadzono zmianę granic rejencji Trewir i Palatynat, włączając nieliczne gminy do Kraju Saary. Brytyjczycy i Amerykanie zaakceptowali zmiany, choć ostateczny ich przebieg miał określać układ pokojowy z Niemcami.

${ }^{4}$ O jego roli świadczy fakt, iż niektórzy określali go mianem ,prokonsula”. 
największym poparcie wyborców - co potwierdzały wybory do Landtagu - Chrześcijańską Partią Ludową (CVP) obrały kurs w zasadzie afirmujący unię gospodarczą z Francją.

Ważną rolę władze w Paryżu przywiązały do wypracowania konstytucji związanego z nim obszaru. Powołano w tym celu specjalną komisję na czele z politykiem CVP Johannesem Hoffmannem, która w 1947 r. przedstawiła propozycję konstytucji Kraju Saary. Za jej podstawę przyjęto polityczną niezależność Saary od Niemiec i związki gospodarcze z Francją - co znalazło wyraz w preambule aktu konstytucyjnego, przyjętego formalnie 15 grudnia 1947 roku. Francuski Wysoki Komisarz decydował o akceptacji wszystkich ustaw przyjmowanych przez miejscowy Landtag, dysponując prawem weta (Paul, 1991, s. 44). Konstytucja nigdy nie została poddana pod głosowanie w referendum. Można jednak domniemywać, iż społeczeństwo Saary akceptowało jej treść, dając temu wyraz w wyborach do Landtagu z października 1947 r. (zdecydowane zwycięstwo CVP Hoffmanna) $)^{5}$. Hoffmann stanął na czele pierwszego rządu Saarlandu (Elzer, 2008, s. 58-59).

Doprowadzenie do przyjęcia konstytucji można określić mianem rozwiązania prowizorycznego, bowiem reszta aliantów nie wyraziła wprost poparcia dla tego rodzaju działań. Tym bardziej trudno byłoby mówić o niezależności Saary w ogóle. Obszar ten znalazł się w unii celnej, gospodarczej i walutowej ${ }^{6} \mathrm{z}$ Francją, obowiązywały tam wszelkie umowy zawierane przez państwo francuskie.

Preambuła konstytucji przewidywała także przeniesienie spraw obrony na rzecz Francji. Saara została włączona do 6 obszaru wojskowego. Co istotne, francuski przedstawiciel w Kraju Saary dysponował wyłącznym prawem wprowadzenia stanu wyjątkowego (także w momencie - jak to określono - zagrożenia niezależności).

Również prowadzenie polityki zagranicznej zostało scedowane na rzecz Francji. Wyjątkiem były jedynie kontakty wzajemne, które regulowano przez umowy określane mianem tzw. konwencji. 3 marca 1950 r. w Paryżu podpisano 12 konwencji i umów, najważniejszą z nich była konwencja o wprowadzeniu unii gospodarczej. W konwencji ogólnej zaznaczano, że Saara jest autonomiczna, lecz autonomia ta rozciąga się w ramach naznaczonych konstytucją i preambułą do niej. Między 1947 a 1950 r. nawiązano także inne umowy kształtujące wzajemne kontakty (dotyczące np. spraw socjalnych, komunikacji pocztowej, a także kultury - na mocy tej ostatniej język francuski został wprowadzony jako obowiązkowy do szkół podstawowych w drugim roku nauki) (Regitz, 1958, s. 70-72).

Wszystkie dziedziny życia gospodarczego zostały zdominowane przez Francję. Do końca 1947 r. przejęto całkowicie nadzór nad kopalniami (w 1950 r. Francja zrezygnowała w ich przypadku z prawa własności na rzecz Saarlandu), tworząc tzw. Régie des Mines, także przemysł stalowy został poddany przymusowej administracji. Kolej również została poddana nadzorowi francuskiemu. Ciągle pozostawał natomiast otwarty status Saary w przyszłości, kwestia jego międzynarodowego uznania i ewentualna pogłębiająca się autonomia tego obszaru (Elzer, 2007, s. 47).

${ }^{5}$ W wyborach do Landtagu ponad 51\% wyborców poparło CVP. Zob. też: http://www.wahlen-in-deutschland.de/blSaar.htm, 16.06.2020.

${ }^{6}$ Formalnie frank francuski został wprowadzony jako oficjalna waluta w Saarze 15 listopada $1947 \mathrm{r}$. 


\section{Przyjęcie Saary do Rady Europy}

Bezpośrednio po zakończeniu wojny wielokrotnie podkreślano, iż ostateczne określenie statusu Saary będzie dokonane w traktacie pokojowym z Niemcami. Nigdy nie doszło do podpisania takiego dokumentu, w związku z czym obie strony - a w szczególności Francja jako mocarstwo zwycięskie - mogły korzystać z argumentacji pozostawiającej otwarte pole do interpretacji. Utworzenie z kolei Republiki Federalnej Niemiec z zachodnich stref okupacyjnych spowodowało sytuację, w której Saara stawała się potencjalnym obszarem konfliktu niemiecko-francuskiego. Mogło to negatywnie rzutować na zbliżenie obu państw - warunku niezbędnego dla powodzenia integracji europejskiej, o czym wspominał chociażby Winston Churchill w swojej słynnej mowie z jesieni 1946 r. w Zurychu.

Proces integracji zachodniej części Starego Kontynentu nabierał stopniowo kształtu, którego wypełnieniem było powstanie organizacji o charakterze politycznym i gospodarczym (EWWiS, EWG). Jednak wcześniej, w maju 1949 r., powołano do życia w Londynie organizację mającą funkcjonować na zasadzie współpracy międzyrządowej, którą była Rada Europy.

Członkami założycielami było 10 państw, lecz zdawano sobie powszechnie sprawę z faktu, iż wcześniej czy później członkiem Rady powinna zostać także Republika Federalna Niemiec, niejako domykając proces związania tego państwa z Zachodem. Włączenie RFN we współpracę zachodnioeuropejską miało być pomysłem na jej kontrolę, a zarazem na korzystanie z potencjału gospodarczego tego państwa.

Francja wiązała z nową organizacją plany dotyczące Kraju Saary. Poprzez jego przyjęcie do Rady Europy zamierzała zyskać międzynarodowe uznanie dla niezależnego istnienia tego obszaru ${ }^{7}$. Okazało się, że realizacja tego zamiaru była w praktyce niemożliwa.

Statut Rady Europy w art. 5 dopuszczał członkostwo w organizacji na zasadzie stowarzyszenia. Umożliwiało to przedstawicielom takiego członka branie udziału w obradach Zgromadzenia Doradczego ${ }^{8}$ (odpowiedniku wspólnego parlamentu), lecz wykluczało udział w Komitecie Ministrów, jedynym organie decyzyjnym, gdyż do tego dopuszczano wyłącznie przedstawicieli państw uznanych na gruncie prawa międzynarodowego (Statut ...; Regitz, 1958, s. 73-74). W praktyce oznaczało to, że przyjęcie Saary do Rady Europy na zasadzie pełnego członkostwa będzie nierealne.

Przedstawiciele Francji przy wielu okazjach podkreślali jaki jest cel ich polityki odnośnie do Saarlandu. Latem 1949 r. minister spraw zagranicznych Robert Schuman wyrażał dążenia Paryża do przyjęcia Saary do Rady Europy, lecz nie spotkał się z pozytywną reakcją Rady. Akcentowano, że Saara powinna zostać autonomiczna, gospodarczo powiązana z Francją, jednocześnie taki jej status powinien stać się punktem dalszego porozumienia z Niemcami. Z prowadzonych rozmów wyraźnie wynikało, iż próbowano doprowadzić do takiej sytuacji, aby Kraj Saary znalazł się w Radzie Europy, nawet wcześniej niż RFN. Celu tego nie udało się zrealizować, tym bardziej, że znad Renu dochodziły negatywne reakcje w tej sprawie, wyrażane m.in. przez póź-

7 Trudno użyć określenia „państwo” bowiem Saara nie była uznana na arenie międzynarodowej za niezależny twór, nawet przez Francję.

${ }^{8}$ Od 1974 r. funkcjonuje pod nazwą Zgromadzenie Parlamentarne. 
niejszego prezydenta Theodora Heussa, stojącego na czele SPD Kurta Schumachera czy Jakoba Kaisera - czołowego polityka CDU. Początkowo wstrzemięźliwość w wypowiedziach okazywał natomiast kanclerz Adenauer (Enders, 1990, s. 24-29).

Jednak podczas konferencji prasowej w styczniu 1950 r. kanclerz zwrócił uwagę, iż jeśli pod pojęciem szerszej autonomii dla Saary będzie rozumiane jej trwałe oddzielenie od Niemiec, to przeciwko temu jego rząd będzie musiał protestować, podobnie jak w przypadku ustalenia granicy na Odrze i Nysie Łużyckiej jako jednostronnemu aktowi ze strony ZSRR (Enders, 1990, s. 36). Mogło to oznaczać ewentualne fiasko integracyjnych planów w zachodniej części kontynentu. Biorąc pod uwagę politykę wewnętrzną RFN poparcie przez zarówno rządzących, jak i opozycję planów wejścia tego państwa do Rady Europy stawało pod znakiem zapytania (Müller-Roschach, 1980, s. 15). W tym kontekście charakterystyczne było stanowisko SPD, która od samego początku stała na stanowisku konieczności utrzymania jedności niemieckiej i rozumiejąc żądania Francji związane z reparacjami, jak i potrzebę pojednania niemiecko-francuskiego, odrzucała dążenia aneksjonistyczne zachodniego sąsiada związane z obszarem Saary.

Do przełomu doszło wiosną 1950 r., w związku z czym trudno nie dostrzec tu związku z rozmowami francusko-niemieckimi dotyczącymi zaprezentowanego 9 maja tzw. planu Schumana - utworzenia Europejskiej Wspólnoty Węgla i Stali. Tego samego dnia rząd federalny zdecydował o przyjęciu zaproszenia do członkostwa w Radzie Europy. Przewidziane w planie Schumana uwspólnotowienie przemysłu surowcowego stwarzało także szansę dla Saary ${ }^{9}$. Przedstawienie planu bez żadnych wątpliwości należy uznać za decydujące wydarzenie umożliwiające wejście także Kraju Saary do Rady Europy (Enders, 1990, s. 42-44).

Ostatecznie RFN została członkiem stowarzyszonym Rady Europy 13 lipca, Kraj Saary 3 sierpnia 1950 r. Do ówczesnego Zgromadzenia Doradczego Rady RFN mogło wysłać 18 przedstawicieli, Saara 3. Nie oznaczało to bynajmniej, aby status pogranicznego obszaru, ciągle powiązanego z Francją uległ wyklarowaniu. To dokonywało się dopiero w latach następnych.

Przystąpienie Kraju Saary do Rady Europy jako członka stowarzyszonego, a więc wówczas na takiej samej zasadzie jak Republika Federalna Niemiec ${ }^{10}$, było pewnym sukcesem dyplomacji francuskiej. Z drugiej jednak strony nie oznaczało to jakiegokolwiek przyznania przez społeczność międzynarodową, iż obszar też można traktować jako niezależny twór. Z punktu widzenia RFN był to istotny krok na drodze ku integracji z Zachodem (koncepcja Westbindung), a także ku uznaniu pełnej suwerenności państwa zachodnioniemieckiego.

\section{Ostateczne regulacje dotyczące położenia Kraju Saary i jego wlączenie do RFN}

W kolejnych latach Francja podejmowała próby uznania rzekomej samodzielności Saary na arenie międzynarodowej. Czyniono to już w innej sytuacji europejskiej

${ }^{9}$ W pracach przygotowawczych do traktatu powołującego EWWiS Francuzi próbowali, bez powodzenia, przeforsować stanowisko, aby Saara została 7 członkiem Wspólnoty.

${ }^{10}$ RFN otrzymała pełny status członkowski Rady Europy w 1951 r. po rewizji statutu okupacyjnego Niemiec i uznaniu tego państwa za w pełni niezależne. 
polityki, gdyż powstała EWWiS i współpraca w jej ramach uległa pogłębieniu, czego wyrazem stały się traktaty rzymskie z 1957 r. Zachodnie Niemcy stały się istotnym składnikiem tego procesu, jego rozwoju nie można było sobie wręcz wyobrazić bez udziału tego państwa.

W 1951 r. w Saarze wprowadzono zakaz działalności nowej partii, Demokratycznej Partii Saary (DPS), która w swoim programie deklarowała działanie na rzecz równoważnych stosunków z Francją i Niemcami. Niemcy zgłaszały na to wielokrotnie uwagę (Erklärung...) gdyż stało to w oczywistej sprzeczności ze statutem Rady Europy, nie wspominając o konstytucji Kraju Saary. Sytuacja ta unaoczniała potrzebę dalszych rozmów dotyczących funkcjonowania Saary.

W kolejnym roku RFN i Francja podjęły rozmowy mające na celu tzw. europeizację Saary. Pod tym terminem należy rozumieć próbę utworzenia z Saary europejskiego terytorium, co zakończyłoby spór niemiecko-francuski i przyczyniłoby się do rozwiązania istniejących problemów w duchu porozumienia. Było to możliwe, wziąwszy pod uwagę powstający wspólny europejski obszar gospodarczy i celny. Problemy dotyczyły jednak natury politycznej, ponieważ oznaczałoby to w praktyce oddzielenie tego obszaru od Niemiec. Natrafiło to na opór w samej Saarze, czego wynikiem były wyniki wyborów do miejscowego parlamentu z listopada 1952 r. Ponownie zakończyły się one zwycięstwem CVP (prawie 55\% poparcia), lecz oddano w nich aż 24,5\% głosów nieważnych (sic!). Nie był to przypadek (Regitz, 1958, s. 75-77).

Wypełnieniem planów europeizacji miał być nowy statut Kraju Saary, który zamierzano poddać pod głosowanie powszechne. Odnośnie do ograniczeń nałożonych w Saarze na wspomniane ugrupowanie DPS rząd niemiecki przedstawił memorandum w tej sprawie, które dotarło do Zgromadzenia Doradczego Rady Europy. Samo zgromadzenie nie podjęło szerszej debaty na ten temat, lecz powołało komisję pod przewodnictwem Holendra van Natersa ${ }^{11}$, która miała przedstawić sprawozdanie w tej sprawie. Miało ono odnosić się także do przyszłego statusu tego obszaru. Przedstawiono je we wrześniu 1953 r. Van Naters proponował aby Kraj Saary był terytorium europejskim. Istotna część propozycji van Natersa znalazła się w porozumieniu francusko-niemieckim podpisanym w kolejnym roku. Nie bez znaczenia dla propozycji był fakt, że w 1954 r. upadł projekt utworzenia Europejskiej Wspólnoty Obronnej (tzw. plan Plevena) (Müller-Roschach, 1980, s. 47; Regitz, 1958, s. 78-79).

Ostatecznie Niemcy i Francja porozumiały się w sprawie Saary w formie dokumentu znanego pod nazwą Umowa o statucie Saary, podpisanego 23 października 1954 roku (Wortlaut..., s. 268-270). Stało się to przy okazji podpisania układów paryskich znoszących status okupacyjny RFN i umożliwiających wejście tego państwa do Unii Zachodnioeuropejskiej i Paktu Północnoatlantyckiego. Podpisanie statutu Saary było kompromisem, strona francuska uzależniała od niemieckiego podpisu pod tym dokumentem swoją zgodę na zniesienie statusu okupacyjnego RFN.

Dokument przewidywał nadanie Saarze europejskiego statutu w ramach Unii Zachodnioeuropejskiej, pod warunkiem jego akceptacji w referendum. Interesy obszaru odnośnie do spraw zagranicznych i obronnych miał reprezentować europejski komisarz, on też reprezentowałby Saarę podczas spotkań ministrów spraw zagranicznych

${ }^{11}$ Od jego nazwiska często mowa jest o tzw. planie Natersa dotyczącym europeizacji Saary. 
państw członkowskich EWWiS (w czasie innych spotkań byliby obecni ministrowie rządu Saary z prawem głosu). Pod względem gospodarczym zachowane miały zostać dotychczasowe związki z Francją (wspólny rynek), ale z czasem przewidywano wprowadzenie podobnych rozwiązań w stosunku do RFN (Wortlaut..., s. 268-270). Widoczna była chęć włączenia obszaru we współpracę zachodnioeuropejską. W artykule 13 statutu znalazło się sformułowanie, iż rządy RFN i Francji zaproponują pozostałym członkom EWWiS przeniesienie siedziby organizacji do Saarbrücken (Wortlaut..., s. 270). Miała być to zatem propozycja stwarzająca z Kraju Saary swoistą „stolicę Europy”. Statut w referendum mieli zaaprobować mieszkańcy Kraju Saary.

Do referendum doszło 23 października 1955 r. Prowadzone badania opinii publicznej wskazywały, iż statut może zostać nieprzyjęty. W sierpniu 52\% ankietowanych przez EMNID Institut odrzucało propozycje z Paryża, wspierało je jedynie 14\% (Altmeyer, Sinnwell, 1958, s. 85-86). Wskazywało to na zmianę postaw społecznych bowiem jeszcze w kwietniu tylko $21 \%$ badanych opowiadało się za przyjęciem propozycji, 20\% przeciw, a reszta była niezdecydowana (Lappenküper, 2001, s. 1080).

Wyniki te potwierdziły się w głosowaniu i dokument został odrzucony większością 67,71\% głosów, mimo iż do europeizacji tego obszaru nawoływali zarówno kanclerz Adenauer, jak i premier Saary Johannes Hoffmann ${ }^{12}$ (Deutschland-Frankreich, 1988, s. 21).

Tak jednoznacznego wyniku referendum nie można było lekceważyć. Propozycja europeizacji Saary, stworzenia z niej obszaru europejskiego, ostatecznie upadła. Także dłuższe jego pozostawanie w bliskim związku z Francją stanęło pod znakiem zapytania, tym bardziej w obliczu postępującej integracji zachodniej Europy.

Konsekwencją wyników głosowania było podanie się do dymisji gabinetu Hoffmanna i przeprowadzenie wyborów do Landtagu jeszcze w grudniu 1955 r. Wygrała je CDU (25,4\% poparcia). CVP Hoffmanna uzyskała 21,8\% głosów i 12 mandatów w miejscowym parlamencie, podczas gdy wcześniej miała ich 29. Była to dotkliwa porażka tego ugrupowania (Altmeyer, Sinnwell, 1958, s. 95-96). Hoffmanna oskarżano o sprzyjanie Francji, na jednej z ulotek znalazło się jakże wymowne hasło, iż wszystkie drogi Hoffmanna prowadzą do Paryża, a separatyści z Saary są narzędziami w rękach Francuzów (Elzer, 2008, s. 805).

Wkrótce Francja i RFN porozumiały się w drażliwej kwestii w duchu pojednania europejskiego. 27 października 1956 r. w Luksemburgu oba państwa podpisały traktat dotyczący regulacji kwestii Saary (Vertrag..., s. 658-661). Kraj Saary, jak wyraźnie zaznaczano, przestał być przedmiotem różnicy zdań. Francja godziła się na rozszerzenie zasięgu działania niemieckiej Ustawy Zasadniczej na obszar Saary. Tym samym możliwe stało się włączenie dotychczasowego protektoratu w skład RFN. Gospodarcze połączenie następować miało stopniowo, najpóźniej do końca 1959 r. (w praktyce miało to miejsce 5 lipca tegoż roku). Obie strony ustaliły, przy współudziale innych członków EWWiS, kanalizację Mozeli i rozbudowę górnego Renu w kierunku jego rozwoju jako drogi wodnej (Deutschland-Frankreich, 1988, s. 21).

Na mocy osobnej ustawy z 23 grudnia 1956 r. (Gesetz über die Eingliederung des Saarlandes; http://www.verfassungen.de...) z dniem 1 stycznia 1957 roku Kraj Saary

${ }_{12} \mathrm{~W}$ praktyce oznaczało to votum nieufności wobec premiera Hoffmanna. 
został 10 landem Republiki Federalnej Niemiec, co zasadniczo było rozwiązaniem najbardziej logicznym z możliwych. Doszło do tego na podstawie art. 23 niemieckiej Ustawy Zasadniczej z 1949 r. (analogicznie w 1990 r. włączono NRD do RFN). Włączenie Saary do RFN określane jest mianem „małego zjednoczenia”.

\section{Inne aspekty niezależności Saary}

Odpowiedź na pytanie czy Kraj Saary był niepodległym państwem, niezależnym obszarem, wydaje się jednoznaczna i może być w opinii autora wyłącznie negatywna. Wprowadzone tzw. obywatelstwo Saary oznaczało, iż każdy kto je nabywa traci jednocześnie obywatelstwo niemieckie. Z punktu widzenia RFN było to rozwiązanie nie do przyjęcia (Elzer, 2007, s. 47). W pewnych obszarach można dopatrywać się autonomii Saary, w konsekwencji uzasadnione jest określanie jej położenia międzynarodowego mianem quasi protektoratu (Elzer, 2008, s. 845). Nie rzadziej używa się po prostu słowa protektorat. I to wydaje się uzasadnione.

Warto zwrócić uwagę na pewne aspekty, symbole, które można uznać za znamiona niezależności, bądź podkreślania takich dążeń, analizowanego obszaru. Kraj Saary posiadał własną flagę, godło i hymn. Korzystano z nich podczas oficjalnych uroczystości, można uznać, iż były w powszechnym użyciu, także podczas wydarzeń sportowych. Trudno jednak uznać, iż owa symbolika była dowodem na pełną niezależność.

Wyrazem niezależności była także aktywność sportowa na tym obszarze. W latach 1950-57 istniał Narodowy Komitet Olimpijski Saary, a na olimpiadę w Helsinkach w 1952 r. wysłano 36-osobową ekipę, która nie odnotowała jednak znaczących sukcesów (https://www.sports-reference.com...). W 1956 r. sportowcy Saary wchodzili w skład wspólnej olimpijskiej ekipy niemieckiej w Melbourne. Therese Zenz zdobyła dla tej ekipy srebrny medal w kajakarstwie, będąc już wcześniej mistrzynią świata (http://www.saar-nostalgie.de...).

Powołano również do życia miejscowy związek piłkarski (SFB), który w $1950 \mathrm{r}$. przyjęto do FIFA. Pierwszy oficjalny mecz narodowa drużyna piłkarska ${ }^{13}$ rozegrała 22 listopada 1950 r. pokonując Szwajcarię B 5:314 (http://www.national...). Do 1956 r. reprezentacja ta rozegrała 19 oficjalnych spotkań międzypaństwowych (http://www. rsssf.com...) biorąc m.in. udział w eliminacjach do mistrzostwa świata, które miały miejsce w 1954 r. W grupie eliminacyjnej Kraj Saary spotkał się z późniejszym mistrzem świata - RFN.

Spotkania te wywołały duże zainteresowania świata polityki. Strona niemiecka nie zgodziła się na to, aby przed spotkaniami odegrano hymn Kraju Saary i aby powieszono jego flagę. W wyniku kompromisu podczas pierwszego spotkania w Stuttgarcie (3:0 dla RFN) odegrano jedynie pieśń FIFA i powieszono flagi Holandii (skąd pochodził sędzia) oraz flagi obu związków piłkarskich (Das Saarland...). Podobne rozwiązanie przyjęto podczas rewanżu na Ludwigsparkstadion w Saarbrücken, przy obec-

13 Jej istnienie nie było rzecz jasna przejawem pełnej niezależności politycznej, świadczy o tym chociażby funkcjonowanie piłkarskich reprezentacji Szkocji, Walii, Irlandii Północnej czy Gibraltaru - także członków FIFA, które nie są przecież obszarami w pełni samodzielnymi.

${ }^{14}$ Większość oficjalnych spotkań reprezentacja Saary rozegrała z drużynami B innych państw. 
ności 53 tys. widzów, gdy Saara uległa 1:3. Świadkowie wydarzeń skłaniają się ku stwierdzeniu, iż wydarzenie sportowe było na pierwszym planie ${ }^{15}$ (Das Saarland...). Faktem jest jednak, że świat polityki mieszał się w tym wypadku ze światem sportu. Trenerem reprezentacji Saary był Helmut Schön, późniejszy selekcjoner RFN.

Istniała także liga piłkarska, choć najlepszy klub piłkarski - 1. FC Saarbrücken - brał początkowo udział we współzawodnictwie drugiej ligi francuskiej. Wygrał nawet jej rozgrywki, lecz klubowi nie pozwolono na udział w grze na najwyższym szczeblu piłkarskim Francji. W 1952 r. klub został wicemistrzem zachodnich Niemiec (rozgrywki toczyły się systemem pucharowym). Z kolei w sezonie 1955/56 wziął udział w rozgrywkach Pucharu Europejskich Mistrzów Krajowych, co było konsekwencją członkostwa Kraju Saary w UEFA i FIFA. Wszystko to wskazuje, że również na tym polu próbowano podkreślić niezależność Kraju Saary szczególnie do RFN.

\section{Podsumowanie}

Terytorium Kraju Saary stało się po zakończeniu II wojny światowej atrakcyjne dla Francji przede wszystkim z powodów gospodarczych (złoża węgla kamiennego i rozwinięty przemysł). Dlatego władze w Paryżu dążyły do jego podporządkowania. Początkowo obszar ten został włączony do francuskiej strefy okupacyjnej, w kolejnych latach Saara była związana z Francją unią gospodarczą i walutową przy zachowaniu pozornej niezależności politycznej. Wyrazem tego było m.in. przyjęcie analizowanego terytorium do Rady Europy jako członka stowarzyszonego.

W momencie postępów w procesie integracji zachodniej części kontynentu europejskiego, utworzenia EWWiS, pojawił się projekt tzw. europeizacji Kraju Saary - tworzenia z niej obszaru europejskiego, nadzorowanego w praktyce przez europejskiego komisarza. Statut Kraju Saary nie został jednak zaaprobowany przez mieszkańców regionu w referendum w 1955 r., co wymusiło zmianę polityki.

W konsekwencji upadku przedstawionego planu z dniem 1 stycznia 1957 r. Saara weszła w skład RFN. Tym samym francuska polityka wobec tego obszaru okazała się nieskuteczna. Działania Paryża były niemożliwe do zrealizowania m.in. z powodu braku francuskiego elementu etnicznego w Saarze. Z gospodarczego punktu widzenia po utworzeniu EWWiS francuskie potrzeby związane choćby z dostawami węgla mogły być zaspokojone bez konieczności podporządkowania sobie tego terytorium. Zapewne włączenie do RFN nie byłoby także możliwe bez dokonującej się - z sukcesem - integracji europejskiej.

\section{Bibliografia}

Altmeyer K., Sinnwell E. (1958), Die Volksbefragung vom 23. Oktober 1955 und die Eingliederung des Saarlandes in die Bundesrepublik, w: Das Saarland. Ein Beitrag zur Entwicklung des jüngsten Bundeslandes in Politik, Kultur und Wirtschaft, red. K. Altmeyer, J. Szliska, W. Neauthier, P. Weiant, Saarbrücken.

15 Opinia Alberta Wagnera, honorowego prezydenta związku piłkarskiego Saary. 
Batowski H. (2001), Między dwiema wojnami 1919-1939. Zarys historii dyplomatycznej, Kraków.

Das Saarland - Kleines Land, großer Fußball, https://www.youtube.com/watch?v=kyNXYcrMLKI, 22.06.2020.

Deutschland-Frankreich. Ein neues Kapitel ihrer Geschichte 1948-1988 (1988), Bonn.

Elzer H. (2007), Die deutsche Wiedervereinigung an der Saar. Das Bundesministerium für gesamtdeutsche Fragen und das Netzwerk der prodeutschen Opposition 1949 bis 1955, St. Ingbert.

Elzer H. (2008), Konrad Adenauer, Jakob Kaiser und die , kleine Wiedervereinigung”. Die Bundesministerien im außenpolitischen Ringen um die Saar 1949 bis 1955, St. Ingbert.

Enders U. (1990), Der Konflikt um den Beitritt der Bundesrepublik und des Saargebiets zum Europarat, w: L. Herbst, W. Bührer, H. Sowade, Vom Marshallplan zur EWG. Die Eingliederung der Bundesrepublik Deutschland in die westliche Welt, München.

Erklärung der Bundesregierung vor dem Deutschen Bundestag zur Saarfrage am 18. November 1952 (1972), w: Die Auswärtige Politik der Bundesrepublik Deutschland, Köln.

http://www.national-football-teams.com/country/273/1950/Saarland.html, 14.05.2020.

http://www.rsssf.com/miscellaneous/saar-recintlp.html, 17.06.2020.

http://www.saar-nostalgie.de/, 15.06.2020.

http://www.verfassungen.de/de/saar/gesetz56.htm, 20.04.2020.

https://www.sports-reference.com/olympics/countries/SAA/summer/1952/, 14.06.2020.

Lappenküper U. (2001), Die deutsch-französischen Beziehungen 1949-1963, Bd. 1: 1949-1958, München.

Müller-Roschach H. (1980), Die deutsche Europapolitik. Eine politische Chronik, Bonn.

Paul G. (1991), Von der Bastion im Westen zur Brücke der Verständigung. Politische Geschichte 1815-1957, w: Das Saarland. Politische, Wirtschaftliche und kulturelle Entwicklung, Saarbrücken.

Regitz F. (1958), Die Politik der Abtrennung (1945-1955), w: Das Saarland. Ein Beitrag zur Entwicklung des jüngsten Bundeslandes in Politik, Kultur und Wirtschaft, red. K. Altmeyer, J. Szliska, W. Neauthier, P. Weiant, Saarbrücken.

Rudolf H. U., Oswalt V. (red.) (2009), Taschen Atlas. Deutsche Geschichte, Stuttgart.

Statut Rady Europy, przyjęty w Londynie dnia 5 maja 1949 r., Dziennik Ustaw RP 1994, Nr 118, poz. 565, http://isap.sejm.gov.pl/DetailsServlet?id=WDU19941180565, 20.06.2020.

Vertrag zwischen der Bundesrepublik und der Französischen Republik zur Regelung der Saarfrage, w: Die Bundesrepublik und Frankreich: Dokumente 1949-1963 (1997), Bd. 1: Außenpolitik und Diplomatie, red. H. Möller, K. Hildebrandt, München.

Wortlaut des Abkommen zwischen der Regierung der Bundesrepublik Deutschland und der Regierung der Französischen Republik über das Statut der Saar (1972), w: Die Auswärtige Politik der Bundesrepublik Deutschland, Köln.

\section{Streszczenie}

Po zakończeniu II wojny światowej terytorium Kraju Saary stało się problemem spornym między Francją a Niemcami. Francja z powodów ekonomicznych (złoża węgla kamiennego i rozwinięty przemysł) próbowała uzależnić ten obszar od siebie, czego wyrazem była najpierw okupacja, później unia gospodarcza i walutowa, wreszcie próba politycznego uniezależnienia Saary od RFN.

Działania te zakończyły się fiaskiem. Powodem było nieprzyjęcie przez mieszkańców Kraju Saary tzw. statutu Saary w referendum w 1955 r. Od 1957 r. obszar został włączony do RFN 
w wyniku tzw. małego zjednoczenia. Zapewne nie byłoby to możliwe bez pozytywnie postępującej integracji zachodniej Europy (utworzenie EWWiS i EWG).

Słowa kluczowe: Kraj Saary, Rada Europy, Republika Federalna Niemiec, Francja, integracja europejska

\section{Saarland and Beginnings of European Integration}

\section{Summary}

After the end of World War II, the territory of the Saarland became a contentious problem between France and Germany. For economic reasons (hard coal deposits and developed industry), France tried to make this area dependent on itself, which was reflected first by the occupation, then by economic and monetary union, and finally by an attempt to make the political independence of Saar from Germany.

These activities ended in failure. The reason was that the inhabitants of the Saarland did not accept the so-called Statute of the Saarland in a referendum in 1955. From 1957, the area was incorporated into Germany as a result of the so-called little reunification (kleine Wiedervereinigung). This would probably not be possible without the positive progressive integration of Western Europe (creation of the ECSC and EEC).

Key words: Saarland, Council of Europe, West Germany, France, European integration 